Supplement of Atmos. Chem. Phys., 17, 12361-12378, 2017

https://doi.org/10.5194/acp-17-12361-2017-supplement

(C) Author(s) 2017. This work is distributed under

the Creative Commons Attribution 3.0 License.

(c) (1)

\title{
Atmospheric \\ Chemistry \\ and Physics
}

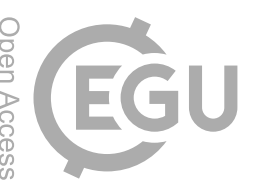

Supplement of

\section{Fast heterogeneous $\mathrm{N}_{2} \mathrm{O}_{5}$ uptake and $\mathrm{ClNO}_{2}$ production in power plant and industrial plumes observed in the nocturnal residual layer over the North China Plain}

Zhe Wang et al.

Correspondence to: Zhe Wang (z.wang@polyu.edu.hk) and Tao Wang (cetwang@polyu.edu.hk)

The copyright of individual parts of the supplement might differ from the CC BY 3.0 License. 
(a)

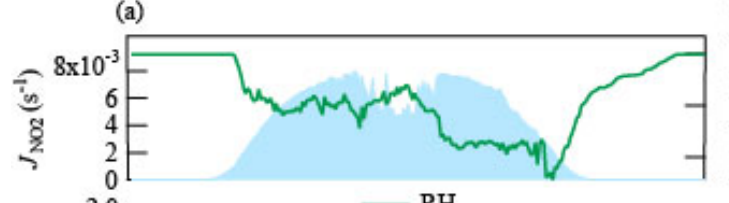

(b)

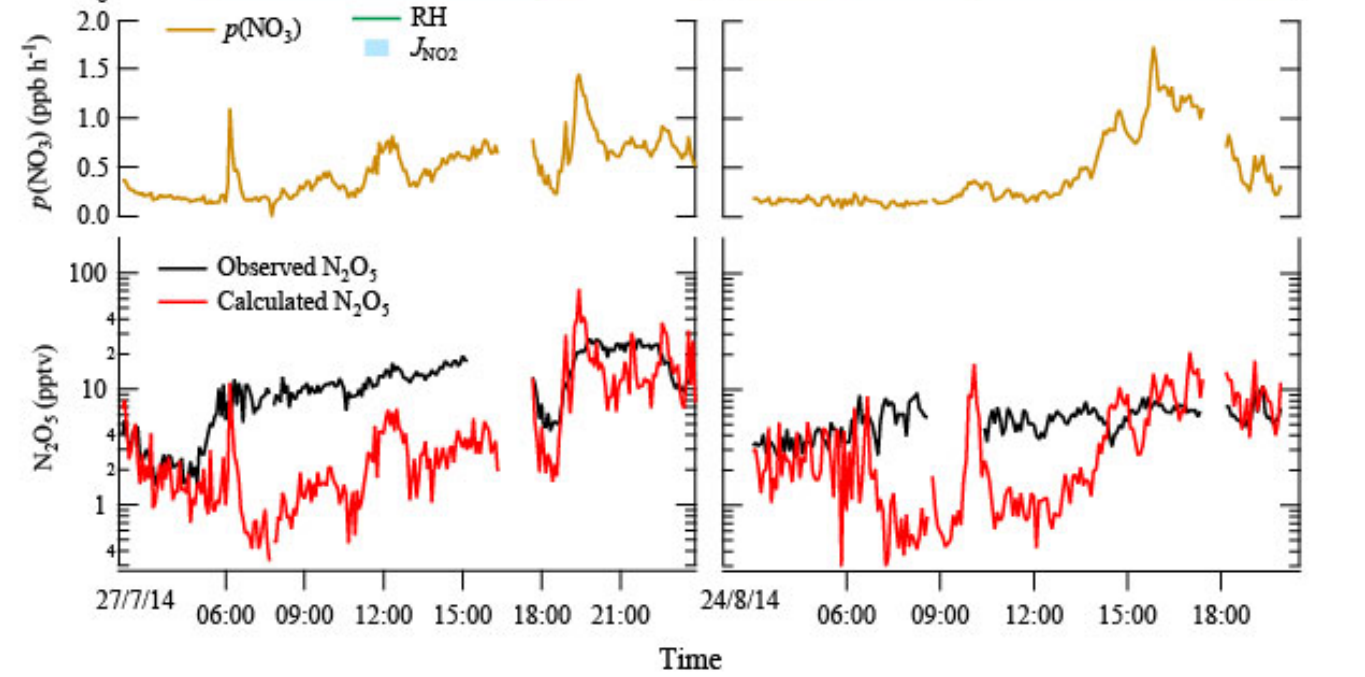

Figure S1: Observed and steady-state calculated daytime $\mathrm{N}_{2} \mathrm{O}_{5}$, nitrate radical production rate and meteorological parameters for the case of (a) 27 July and (b) 24 August, 2014. 

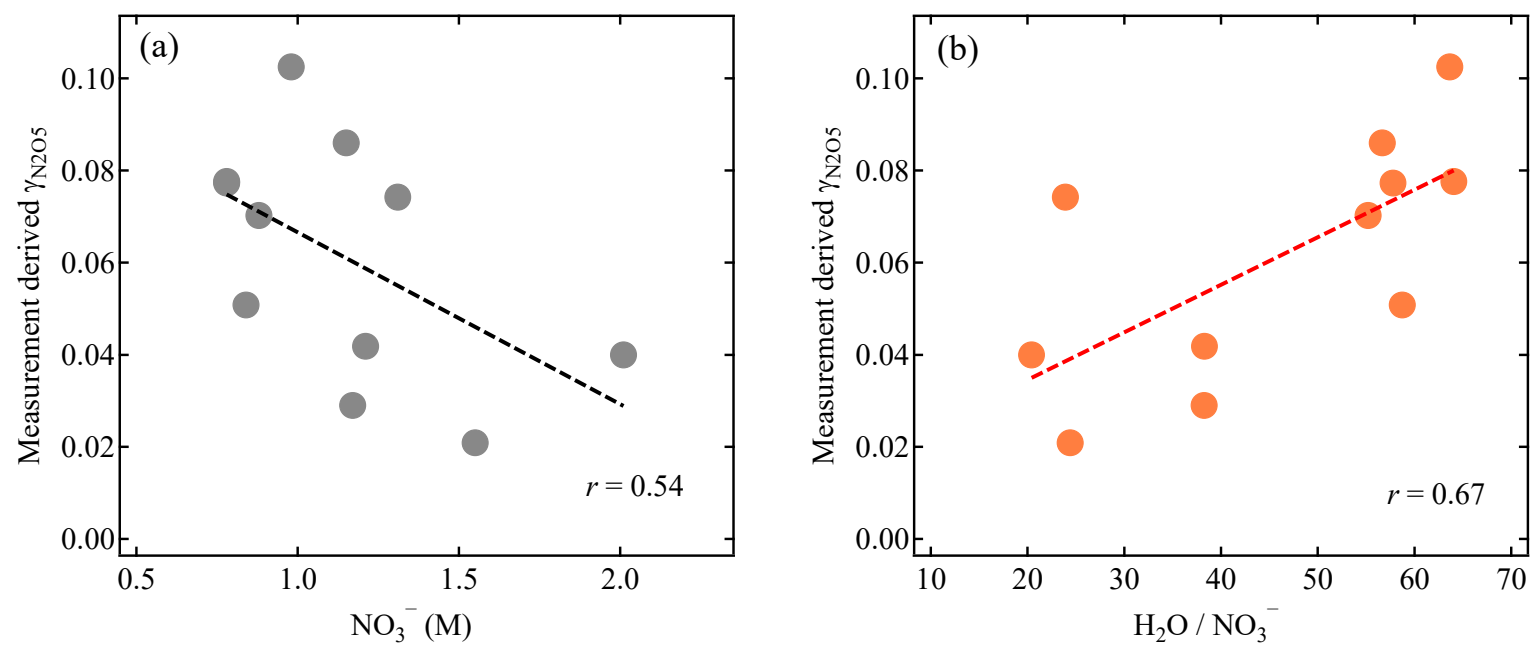

Figure S2: Relationship between derived $\gamma_{\mathrm{N} 205}$ from the measurements with (a) the molar concentration of aerosol nitrate and (b) the molar ratio of aerosol water to nitrate during the study period.
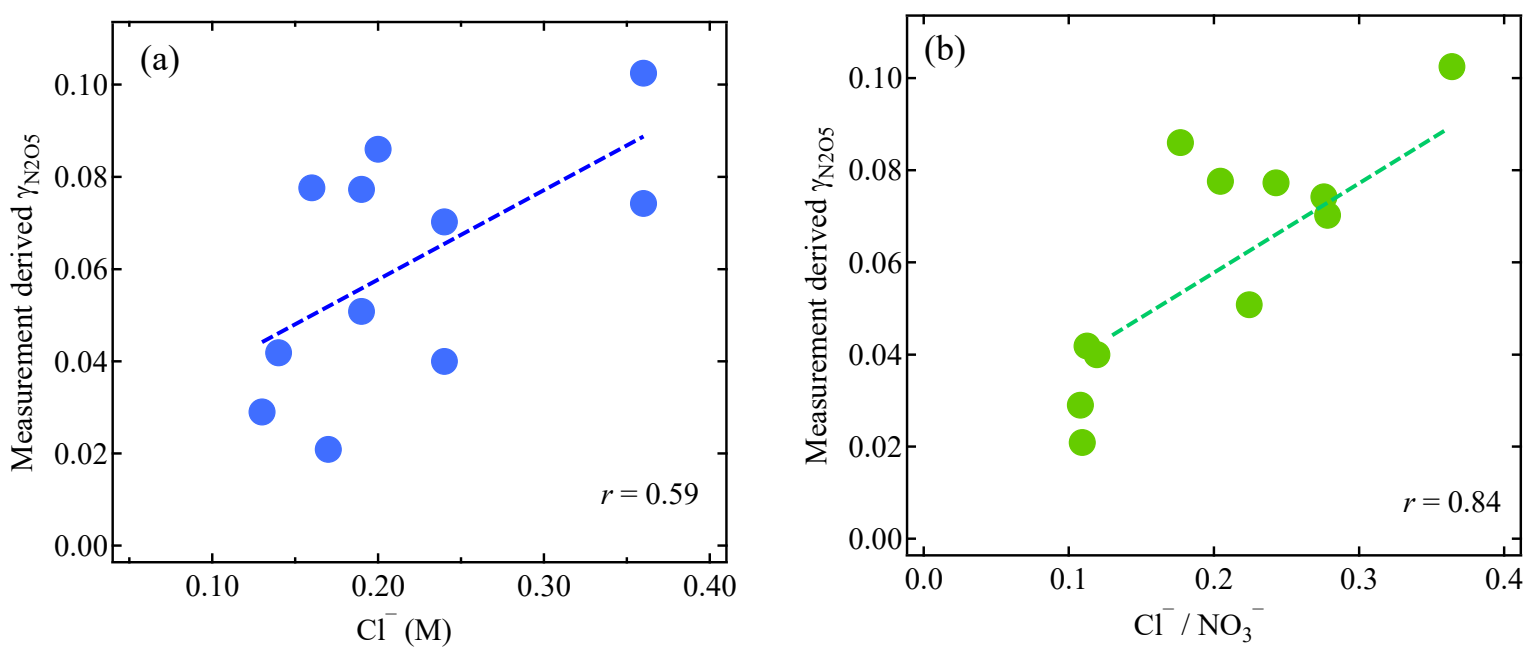

Figure S3: Relationship between derived $\gamma_{\mathrm{N} 205}$ from the measurements with (a) the molar concentration of aerosol chloride and (b) the molar ratio of aerosol chloride to nitrate during the study period. 


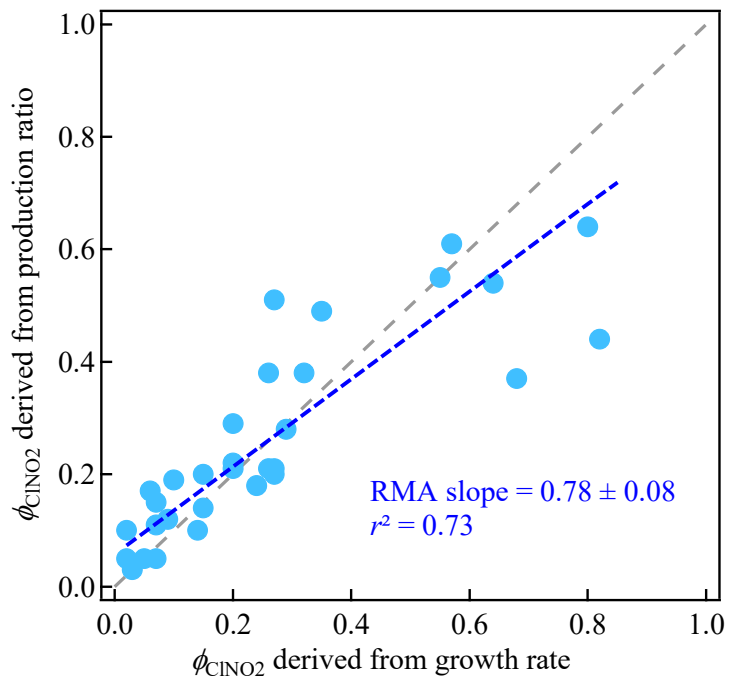

Figure S4: Comparison of estimated $\mathrm{CINO}_{2}$ yields from two different approaches: approach $\mathrm{A}$ using the ratio of the observed CINO growth rate to steady-state $\mathrm{N}_{2} \mathrm{O}_{5}$ loss rate based on Eq. 6; approach $\mathrm{B}$ using the production ratio of observed enhancements of CINO and total nitrate, $\phi=2 /\left(\Delta \mathrm{NO}_{3}{ }^{-} / \Delta \mathrm{CINO}_{2}+1\right)$ according to Riedel et al., 2013. 
Table S1: Mean mixing ratios of VOC species measured in the early morning before sunrise and in the evening during the previous campaign at Mt. Tai in 2007. Bimolecular rate coefficients for VOCs-NO3 reactions were determined following Brown et al. (2011) and Atkinson and Arey (2003).

\begin{tabular}{|c|c|c|c|c|c|}
\hline \multirow{2}{*}{ Species } & \multicolumn{2}{|c|}{ Mean mixing ratio (pptv) } & \multirow[t]{2}{*}{ Species } & \multicolumn{2}{|c|}{ Mean mixing ratio (pptv) } \\
\hline & Early morning & Evening & & Early morning & Evening \\
\hline Alkanes & & & Aromatics & & \\
\hline Ethane & 3372 & 3340 & Benzene & 1238 & 981 \\
\hline Propane & 1331 & 1340 & Toluene & 1872 & 2775 \\
\hline i-Butane & 343 & 411 & Ethylbenzene & 168 & 194 \\
\hline n-Butane & 453 & 591 & m,p-Xylene & 289 & 417 \\
\hline i-Pentane & 1223 & 1385 & o-Xylene & 104 & 143 \\
\hline n-Pentane & 209 & 384 & i-Propylbenzene & 14 & 22 \\
\hline 2-Methylpentane & 1135 & 2095 & n-Propylbenzene & 30 & 47 \\
\hline 3-Methylpentane & 908 & 1598 & $\begin{array}{l}\text { 2-Ethyltoluene, 3- } \\
\text { Ethyltoluene, 4- } \\
\text { Ethyltoluene }\end{array}$ & 127 & 218 \\
\hline n-Hexane & 923 & 1558 & $1,3,5$-Trimethylbenzene & 39 & 59 \\
\hline n-Heptane & 60 & 147 & 1,2,4-Trimethylbenzene & 73 & 167 \\
\hline n-Octane & 32 & 53 & 1,2,3-Trimethylbenzene & 24 & 60 \\
\hline 1,3-Butadiene & 6 & 26 & Biogenic & & \\
\hline 2,2-Dimethylbutane & 113 & 147 & Isoprene & 37 & 53 \\
\hline 2,3-dimethylbutane & 178 & 215 & $\alpha$-pinene & 43 & 51 \\
\hline 2-Methylhexane & 279 & 471 & $\beta$-pinene & 4.8 & 5 \\
\hline 3-Methylhexane & 228 & 459 & DMS & 44 & 33 \\
\hline Cyclohexane (B) & 68 & 127 & & & \\
\hline Alkenes & & & Others & & \\
\hline Ethene & 1733 & 1401 & OCS & 610 & 593 \\
\hline Propene & 127 & 195 & Ethyne & 2637 & 2081 \\
\hline 1-Butene & 29 & 80 & & & \\
\hline i-Butene & 94 & 164 & & & \\
\hline cis-2-Butene & 23 & 53 & & & \\
\hline trans-2-Butene & 17 & 60 & & & \\
\hline 1-Pentene & 18 & 70 & & & \\
\hline trans-2-Pentene & 40 & 44 & & & \\
\hline cis-2-Pentene & 33 & 60 & & & \\
\hline 2-Methyl-1-butene & 38 & 51 & & & \\
\hline 2-Methyl-2-butene & 29 & 36 & & & \\
\hline
\end{tabular}

